EASTERN REVIEW 2018, T. 7

Ryszard Cichocki

\title{
Lokalne sfery publiczne a przemiany kompetencji obywatelskiej
}

Reforma samorządowa, przeprowadzona w najwcześniejszej fazie transformacji systemowa, była jedną z czterech fundamentalnych projektów przebudowy dezorganizującego się społeczeństwa realnego socjalizmu w kierunku modeli wzorowanych na demokracjach zachodnich. Pierwsza z tych reform polegała na zakwestionowaniu niedemokratycznego państwa z monopolem władzy jednej partii i przyjęciu modelu polegającego na zdemokratyzowaniu i pluralizacji sfery publicznej; druga - na zanegowaniu systemu gospodarczego opartego na centralnym planowaniu i monopolizowaniu przez państwo własności ekonomicznej oraz zastąpieniu ich modelem gospodarki opartej na regulacjach rynkowych i oraz własności prywatnej jako formie dominującej; trzecia - na podważeniu monocentrycznego, skrajnie scentralizowanego państwa i zastąpieniu go jednym z alternatywnych modeli decentralizacji państwa i upodmiotowieniu społeczności lokalnych i regionalnych poprzez system samorządu terytorialnego; czwarta - na zakwestionowaniu modelu społeczeństwa zamkniętego, uprzedmiotawiającego obywateli, w którym aktywność obywatelska regulowana jest centralnie poprzez różne formy mobilizacji i kontroli partii dominującej i zastąpieniu go modelem społeczeństwa otwartego, w którym sfera publiczna jest ramą dla budowania podmiotowości społecznej, a aktywność obywatelska ma charakter oddolny i jest regulowana przez ramy prawne i instytucjonalne, z jednej strony, a motywacje do aktywności i kompetencję obywatelską, z drugiej.

U podstaw wszystkich tych reform tkwił - mniej lub bardziej uświadamiany - zamysł reformy kompleksowej gospodarki i państwa, ale takie całościowe koncepcje zmian w sposób nieuchronny prowadzą także do zmian w warstwie społecznej i kulturowej. Wtedy konsekwencje tych ostatnich zmian były dostrzegane jedynie w mglistych zarysach, dziś są widoczne dość wyraźnie i są dla jednych kategorii społecznych obiektem akceptacji, oczekiwanym wzorem i czynnikiem motywującym do aktywności wspierania poprzez aktywność obywatelską, a dla innych dramatem społecznym, trendem zagrażającym istotnym elementom toż- 
samości społecznej i czynnikiem motywującym wielką reakcję konserwatywną, obserwowaną od kilku lat.

Reforma samorządowa była kluczowym elementem demokratyzacji i decentralizacji państwa odziedziczonego po socjalizmie. W obrębie decentralizującego się państwa powstało niemal 3 tys. względnie autonomicznych społeczności, które - w zamyśle twórców reformy - miały uzyskać prawne i instytucjonalne ramy samorządności opartej na czterech podstawach: a) na racjonalnych i kompleksowych rozwiązaniach prawnych dających samorządom terytorialnym względnie szeroki zakres kompetencji i uprawnień; b) na systemie instytucji władzy lokalnej, o oddolnej logice selekcji i funkcjonowania; c) na przydzielonych zasobach materialnych i dość jasno sprecyzowanych dochodach dających samorządom terytorialnym możliwość realizowania polityk na szczeblu lokalnym oraz d) na społecznościach lokalnych, których wartości, potrzeby, aspiracje, oczekiwania i interesy miały być nowymi źródłami kryteriów funkcjonowania władzy samorządowej o ewaluacji jej przyszłych efektów ${ }^{1}$.

Dla socjologa społeczności lokalnych przedmiotem szczególnych obaw był filar czwarty, a obawa sprowadzała się do kwestii:

Czy społeczności lokalne w naszym kraju, pozbawione znaczących tradycji samorządowych, nieposiadające większych doświadczeń w zakresie samoorganizacji i zarządzania własnymi sprawami, ze słabymi lokalnymi elitami wpływu, będą chciały i potrafiły wypełnić aktywnością zbiorową i indywidualną nowe ramy prawne, społeczne i instytucjonalne wykreowane przez reformę samorządową? Czy będą zdolne do uczestnictwa w lokalnej sferze publicznej, jako realny partner władz samorządowych? ${ }^{2}$

Czy w społecznościach lokalnych nie upowszechnią się - silnie wzmacniane przez doświadczenie przeszłości - strategie egoistyczne zorientowane na wartości partykularne, strategie ucieczkowe, wyrażające się w obojętności na sprawy publiczne, niechęci do aktywności w sprawach publicznych.

Jedną z takich odległych konsekwencji, niezbyt jasno dostrzeganych wówczas przez elity polityczne i społeczne, jest proces przemian lokalnych sfer publicznych i kompetencji obywatelskich w społecznościach lokalnych i regionalnych. Celem niniejszego opracowania jest naszkicowanie trendów występujących w kilku aspektach zmian, jakie nastąpiły w od początku lat 90. w lokalnych układach społecznych, ze szczególnym uwzględnieniem przemian lokalnych sfer publicznych i przekształceń kompetencji obywatelskiej³

1 R. Cichocki, A. Kilarska, Życie w Lesznie 2014, Poznań 2015, s. 16-17.

2 Ibidem, s. 17.

${ }^{3}$ M. Somers, Citizenship and the place of the public sphere: Law, community, and the political culture in the transition tu democracy, „American Sociological Review” 1997, no. 58(5). 


\section{Sfera publiczna a lokalna sfera publiczna i jej przemiany}

\section{Koncepcje sfery publicznej}

W literaturze dotyczącej sfery publicznej można wyróżnić jej trzy koncep$\mathrm{cje}^{4}$. Najbardziej upowszechnioną jest ta związana z pracami J. Habermasa ${ }^{5}$, traktująca sferę publiczną w kategoriach dyskursu publicznego, w której przebiegają procesy kształtowania się debat politycznych oraz kreowanie, wymiana i upowszechnianie tych poglądów indywidualnych i zbiorowych, które odnoszą się do różnych aspektów sfery publicznej.

Jednak z punktu widzenia potrzeb tego opracowania bardziej przydatne są dwa inne ujęcia sfery publicznej: M. Sommer ${ }^{6}$ (podkreśla partycypacyjny wymiar sfery publicznej) i D. Pietrzyk-Reeves ${ }^{7}$ (podkreśla elementy konsensusu wspólnych norm i porozumiewania się). Przyjmuje się, iż tak pojmowana struktura sfery publiczna, wyznaczająca przestrzeń aktywności obywatelskiej (zarówno indywidualnej, jak i zbiorowej), obejmuje co najmniej osiem elementów: a) ramy prawne w postaci konstytucji i ustaw regulujących w sposób pośredni i bezpośredni funkcjonowanie sfery publicznej (przede wszystkim ustawa o pożytku publicznym i wolontariacie), b) państwowe ramy instytucjonalne sfery publicznej w postaci systemu parlamentarnego i centralnych instytucji państwa (Parlament, Rząd, Trybunał Konstytucyjny, Naczelny Sąd Administracyjny, Sąd Najwyższy), c) regionalne ramy instytucjonalne sfery publicznej (Sejmik Samorządowy, Urząd Marszałkowski i struktury zależne), e) lokalne ramy instytucjonalne sfery publicznej (rady i zarządy miast i gmin i struktury zależne), f) przedstawicielskie ramy sfery publicznej w postaci partii i struktury systemu partyjnego (partie polityczne, struktury quasi-partyjne), g) obywatelskie ramy sfery publicznej (fundacje i stowarzyszenia trzeciego sektora, zinstytucjonalizowane ruchy społeczne, zinstytucjonalizowane ruchy miejskie) oraz h) spinające te elementy w jedną - mniej lub bardziej spójną - całość aksjologiczne ramy sfery publicznej ${ }^{8}$.

Przez analogię można przyjąć istnienie regionalnej czy lokalnej sfery publicznej. Regionalne sfery publiczne są wyraźnie słabiej ukształtowane, co wynika z faktu, iż jedynie niektóre regiony w naszym kraju mają wyraźnie uformowaną odrębność i skrystalizowane rdzeniowe elementy tożsamość ${ }^{9}$. Natomiast lokalne

${ }^{4}$ E. Wnuk-Lipiński, Socjologia życia publicznego, Warszawa 2008.

5 J. Habermas, Strukturalne przeobrażenia sfery publicznej, Warszawa 2008.

${ }^{6} \mathrm{M}$. Somers, Citizenship and the place...

7 Zob. D. Pietrzyk-Reeves, Idea społeczeństwa obywatelskiego: wspótczesna debata i jej źró$d t a$, Wrocław 2004.

${ }^{8}$ M. Kalisiak-Mędelska, Partycypacja społeczna na poziomie lokalnym jako wymiar decentralizacji administracji publicznej w Polsce, Łódź 2015.

${ }^{9}$ E. Wnuk-Lipiński, Socjologia... 
sfery publiczne, związane z lokalnymi układami społecznymi lub społecznościami lokalnymi, są bardzo zróżnicowane: od dużych miast do niewielkich gmin wiejskich. W dużych miastach występują zarówno bardzo rozwinięte i w pełni ukształtowane ramy sfery publicznej (instytucjonalne i prawne), relatywnie wysoki poziom aktywności obywatelskiej (zarówno na poziomie indywidualnym, poziomie grupowym, jak i w pełni zinstytucjonalizowanym, a nawet sprofesjonalizowanym), jak i nieźle rozwinięte dyskursy publiczne (dzięki obecności mediów i innych narzędzi upowszechniania opinii). Natomiast w małych społecznościach lokalnych sfera publiczna ma z reguły fragmentaryczny charakter (brak mediów, niewielki poziom zaangażowania obywateli, niski stopień zorganizowania i instytucjonalizacji aktywności obywatelskiej, brak skutecznych mediów zdolnych do pełnienia funkcji w sferze publicznej, występowanie lokalnych warunków blokujących rozwój dyskursów publicznych). Jednak czas istnienia samorządu terytorialnego jest bez wątpienia okresem kształtowania się i rozwoju lokalnych sfer publicznych oraz różnych wymiarów kompetencji obywatelskiej, niezbędnej d efektywnego trwania sfery publicznej.

\section{Przemiany lokalnych sfer publicznych}

Znaczący okres od powstania systemu samorządowego w Polsce był zasadniczo wystarczający do ukształtowania się głównych lokalnych sfer publicznych. W wymiarze instytucjonalnym lokalne sfery publiczne mają struktury podobne głównie do społecznej sfery publicznej. Różni je tylko stopień skomplikowania i bogactwo składników. Ramy prawne stanowią regulacje prawne ustawodawcy uzupełnione przez wybrane aspekty prawa regionalnego i lokalnego, stanowionego przez poszczególne szczeble administracji samorządowej. Ramy instytucjonalne konstytuowane są w zasadniczej mierze przez instytucje samorządu terytorialnego: sejmiki wojewódzkie, zarządy województw i urzędy marszałkowskie, rady miast i gmin, prezydentów, burmistrzowów i wójtowów, urzędy miast i gmin. Regionalne i lokalne ramy prawne są zasadniczo podobne zarówno w sensie struktury, jak i funkcji. Przedstawicielskie ramy instytucjonalne to lokalne i regionalne szczeble ogólnokrajowego systemu partyjnego. A głównymi aktorami lokalnych sfer publicznych są oczywiście przede wszystkim władze samorządowe i mieszkańcy, ci ostatni zarówno jako podmioty indywidualne obecne w sferze publicznej, jak i jako uczestnicy różnych zorganizowanych form życia istotnych z punktu widzenia sfery publicznej: partii politycznych, obywatelskich organizacji pozarządowych, ruchów społecznych, organizacji religijnych, grup interesu i innych form zorganizowanych.

Najważniejszym efektem reformy samorządowej było pojawienie się ponad 2700 względnie autonomicznych podmiotów społecznych w państwie o tradycjach silnie centralistycznych, rzec można o charakterze monocentrycznym i w społeczeństwie o niemal żadnych tradycjach samorządowych zapisanych w doświadczeniach społecznych i historycznych. W stosunkowo krótkim czasie 
to pozbawione znaczących doświadczeń samorządowych społeczeństwo zaczęło funkcjonować w nowej logice prawnej i instytucjonalnej. Zasadniczo zmieniło się przede wszystkim generalne usytuowanie społeczności lokalnych w całym systemie społecznym. Z peryferyjnych elementów monocentrycznego państwa, znalazły się w centrach własnych specyficznych mikroświatów społecznych, ekonomicznych i politycznych. Z ładu społecznego organizowanego w głównej mierze wokół wartości i interesów skrajnie niedemokratycznego centrum politycznego, w ład policentryczny, w którym logiką sterującą są systemy negocjowania wartości społecznych i interesów społecznych. Ze zbiorowości, których rozwój lokalny był w zasadniczej mierze określany przez centralnego planistę, na którego nie miały one żadnego wpływu, w zbiorowość, gdzie rozwój lokalny miał być realizowany zgodnie z logiką lokalnych wartości i interesów społecznych i w oparciu o lokalne potencjały społeczne i ekonomiczne. Z systemów władzy lokalnej jednoznacznie zorientowanej w swym funkcjonowaniu na centrum polityczne, w systemy władzy zorientowane na społeczność lokalną.

Które zmiany, zrealizowane w społecznościach lokalnych i regionalnych, jako konsekwencje reform lat 90., wydają się szczególnie istotne dla kształtowania się aktywności obywatelskiej w lokalnych sferach publicznych i budowania związanej z tym kompetencji obywatelskie? Cztery grupy tych zmian warte są uwagi: zmiany prawa, zmiany logiki funkcjonowania systemu instytucjonalnego, zmiany społeczne i zmiany w aksjologiach społeczności lokalnych.

Pierwsza kluczowa zmiana to przejście od państwa reglamentującego prawa i wolności obywatelskie do państwa gwarantującego te prawa. Z interesującego tu punktu widzenia szczególnie istotne były zmiany w zakresie: praw i wolności osobistych, w tym przede wszystkim wolności słowa i wypowiedzi, które stały się podstawą do wolnego myślenia i kształtowania dyskursów politycznych w sferze publicznej i przyczyniły się do zbudowania wolnych mediów oraz praw i wolności polityczne, gwarantujące obywatelowi udział w życiu publicznym. Wśród nich szczególne znaczenie mają prawa wyborcze, prawo do zrzeszania się, prawo do informacji, które stały się podstawą do wolnego działania w sferze publicznej i przyczyniły się do kształtowania się instytucjonalnego wymiaru społeczeństwa obywatelskiego ${ }^{10}$.

Druga kluczowa zmiana to przejście od monocentrycznego systemu politycznego do policentrycznego systemu zdecentralizowanego. Logika funkcjonowania systemu władzy opartego na selekcji jednostek do struktur władzy na podstawie układu politycznego zwanego nomenklaturą gwarantował lojalność lokalnych władców oddelegowanych do zarządzania sprawami społeczności terytorialnych wobec centrum polityczno-partyjnego ${ }^{11}$.

${ }^{10}$ P. Frączak, M. Rogaczewska, K. Wygnański, Stan społeczeństwa obywatelskiego. Próba diagnozy, Warszawa 2005.

${ }^{11}$ Zob. Rozdroża praktyki i idei społeczeństwa obywatelskiego, red. W. Miształ, A. Kościański, Warszawa 2011. 
Bezwzględna dominacja wartości i interesów centrum wbudowana w struktury władzy powodowała, że lokalne źródła kryteriów wartości miały niewielkie możliwości realizacji. W sytuacji konfliktu wykorzystanie własnych zasobów, priorytety rozwojowe, możliwości uzyskania zewnętrznego wsparcia, lokalne wartości musiały być marginalizowane przez wartości centrum, lokalne interesy musiały być stawiane za interesami np. centralnego planisty, potrzeby lokalne, aspiracje lokalne pełniły co najwyżej drugorzędne role. Był to jeden z kluczowych czynników sprzyjających upowszechnianiu się przekonań o braku wpływu społeczeństwa na funkcjonowanie władzy lokalnej i kształtowało poczucie bezsilności i bezradności wobec istniejącego systemu. Nowa, samorządowa organizacja sfery publicznej w społecznościach lokalnych zasadniczo zmieniła logikę relacji pomiędzy władzą lokalną a społecznością lokalną. Zmiana procedur selekcji ludzi do systemu władzy na w pełni zdecentralizowaną i opartą na bezpośrednich wyborach spowodowała zmianę skali wpływu społeczności lokalnej zarówno na sam wybór władz, jak i na późniejsze funkcjonowanie instytucji zarządzanych przez te władze. Autonomiczny rozwój gminy oparty na czynnikach endogennych, wzrost stopnia integracji społeczności lokalnych, przyspieszenie procesu budowania poczucia odrębności miast i gmin, przyspieszenie procesów kształtowania tożsamości lokalnej to czynniki zasadniczo zmieniające warunki aktywności obywatelskiej.

Trzecia kluczowa zmiana to przekształcenia w strukturach aksjologicznych społeczności lokalnych i regionalnych. Lokalne wartości i interesy marginalizowane w ramach społeczeństwa scentralizowanego przez wartości i interesy struktur i grup wpływu wyższego rzędu krystalizowały się i upowszechniały bardzo wolno. Często były one domeną lokalnych pasjonatów i miejscowych patriotów $\mathrm{i}$ jako takie traktowano je $\mathrm{z}$ ograniczoną powagą. Zmiana ram prawnych, ale przede wszystkim zmiana logiki funkcjonowania ram instytucjonalnych spowodowały, iż lokalne potrzeby zaczęły być poważnie przeciwstawiane oczekiwaniom centrów decyzyjnych. Dzięki aktywności władz samorządowych z jednej strony a aktywności obywatelskiej z drugiej stopień werbalizacji i zbiorowego uświadamiania tych potrzeb uległ istotnemu przyspieszeniu. Podobna sytuacja wystąpiła w przypadku lokalnych wartości. Pojawiły się szanse na efektywne konkurowanie lokalnych wartości w konfliktach z wartościami ponadlokalnymi, a interesów lokalnych z zarówno z interesami ponadlokalnymi, jak i czysto partykularnymi. Te zasadnicze zmiany w aksjologii lokalnych układów społecznych stały się czynnikami determinującymi procesy kształtowania się poczucia odrębności społecznej i tożsamości lokalnej ${ }^{12}$.

Czwarta kluczowa zmiana to zasadniczo nowe wzory aktywności indywidualnej i zbiorowej, czyli przejście od systemu społecznego, w którym aktywność obywatelska była bardzo ściśle reglamentowana, a ta legalna odbywała się w zasad-

12 J.H. Kuklinski, J.P. Quirk, Conceptual fundations of citizen competence, „Political Behaviour" 2001, no. 2(23), s. 285-311. 
niczej mierze pod wpływem odgórnej mobilizacji, do systemu opartego na aktywności oddolnej organizowanej w oparciu o własne wartości i interesy oraz regulowanej w zasadniczej mierze przez indywidualną i zbiorową kompetencję obywatelską.

Nastąpiły istotne zmiany na mapach aktywności obywatelskich w społecznościach lokalnych. Wyrażały się one przede wszystkim w gruntownej reorganizacji głównych aktorów lokalnej sfery publicznej. Znacząco wzrosła liczba partii politycznych i gama oferowanych przez nie programów politycznych, co poszerzyło dostępny dla obywateli „rynek oferty politycznej”. Wprawdzie w pierwszym dziesięcioleciu wysoki stopień rozproszenia partii i bardzo niski stopień ich instytucjonalizacji powodowały, że struktury partyjne sięgały jedyne do poziomu dużych miast, a lokalne sceny publiczne w znaczącej skali były pozbawione partyjnych struktur instytucjonalnych, ale już po drugiej reformie samorządowej partie polityczne uzyskały możliwość efektywnego wpływania na lokalne sfery publiczne. Przez swój partykularyzm interesów i ideologiczne zacietrzewienie stawały się często poważnym zagrożeniem dla fundamentów samorządności lokalnej.

Przyrost liczby obywatelskich organizacji pozarządowych trzeciego sektora należy do najbardziej znaczących wskaźników kształtowania się społeczeństwa obywatelskiego w naszym kraju. Proces ten został zintensyfikowany szczególnie po uchwaleniu nowych ram prawnych dla działalności trzeciego sektora. Obecnie należy on do najważniejszych aktorów lokalnych sfer publicznych i jego wpływ zarówno na funkcjonowanie instytucji lokalnych, jak i na kierunki rozwoju społeczności lokalnych jest zupełnie zasadniczy. Komplementarnym - do NGO'sów - segmentem społeczeństwa obywatelskiego na poziomie lokalnym są ruchy społeczne i miejskie ruchy mieszkańców. Te pierwsze mają zwykle zasięg ponadlokalny i ponadregionalny, a $\mathrm{w}$ gminach sytuują się ich peryferyjne agendy, ale zasoby koncepcyjne, finansowe i kadrowe tych ruchów są istotnymi czynnikami wspierającymi ich lokalne agendy. Ich znaczenie jest niekwestionowane szczególnie w przypadkach ukierunkowywania aktywności na cele wynikające $\mathrm{z}$ uniwersalnych wartości i ponadlokalnych interesów ${ }^{13}$. Natomiast miejskie ruchy mieszkańców charakteryzuje znacznie węższy horyzont widzenia spraw społecznych i koncentracja na wartościach lokalnych i - często - partykularnych interesach grupowych. Wreszcie - w związku z decentralizacją - zasadniczemu przeorientowaniu i wzmocnieniu uległy lokalne grupy interesu i lokalne środowiska wpływu. Niestety, nie ma zbyt wiele badań pokazujących ich wpływ na funkcjonowanie i rozwój społeczności lokalnych, ale skrajnie partykularna orientacja tych aktorów sceny (raczej kulisów) politycznej nie pozostawia wątpliwości w tym zakresie. Szczególnie w tych środowiskach, w których grupom interesów udało się opanować i zinstrumentalizować pozostałych aktorów: partie polityczne

13 A. Giza, A. Przybylska, Partycypacja obywatelska: od teorii do praktyki społecznej, Warszawa 2014. 
i organizacje pozarządowe, a mieszkańców zniechęcić do obecności publicznej i usunąć na margines.

Cztery naszkicowane wyżej zmiany stały się nowymi ramami dla formowania się aktywności obywatelskiej i czynnikami kształtowania się kompetencji obywatelskiej na poziomie lokalnym $\mathrm{i}$ - ciągle jeszcze bardzo słabym - regionalnym.

\section{Kompetencja obywatelska i jej przemiany na poziomie lokalnym}

Badania społeczne nad kompetencją obywatelską pozwalają wyróżnić trzy zasadnicze jej typy. Pierwsza to kompetencja podmiotów indywidualnych, jednostek podejmujących aktywność w sferze publicznej (niezależnie, czy motywem tej aktywności są uniwersalne wartości, czy partykularne interesy), druga to kompetencja obywatelska podmiotów zbiorowych, kumulowana w procesach uruchamiania ruchów społecznych (niezależnie, czy są one uniwersalnymi ruchami globalnymi, czy lokalnymi ruchami miejskimi), trzecia to kompetencja obywatelska podmiotów instytucjonalnych, gromadzona w procesach uruchamiania i funkcjonowania społecznych organizacji obywatelskich lub inaczej organizacji pozarządowych (niezależnie od intencji które leżą u podstaw i tworzenia i działania). Przedmiotem tego artykułu jest tylko pierwszy ze wspomnianych typów kompetencji obywatelskiej - kompetencja podmiotów indywidualnych.

\section{Koncepcja kompetencji obywatelskiej}

Na potrzeby tego opracowania przyjmujemy koncepcję „kompetencji obywatelskiej”, której kluczowe założenia do konceptualizacji zostały sformułowane w dwóch pracach: R. Cichockiego pt. Podmiotowość w społeczeństwie ${ }^{14}$ oraz A. Siatkowskiego - Kompetencje obywatelskie a aktywność w sferze publicznej ${ }^{15}$. Kompetencja obywatelska to - w tym ujęciu - zdolność podmiotów indywidualnych i zbiorowych do efektywnej kontroli otoczenia w sferze publicznej w wymiarach: ewaluacyjnym, poznawczym, normatywnym i sprawczym.

Kompetencję obywatelską określam - ogólnie rzecz biorąc - jako ten zespół narzędzi motywacyjnych, ewaluacyjnych, normatywnych, poznawczych i sprawczych pozostających w dyspozycji podmiotów uczestniczących w sferze publicznej (zarówno indywidualnych, jak i zbiorowych), które są niezbędne do efektywnego podejmowania aktywności obywatelskiej w sferze publicznej. Przyjmujemy tu konceptualizację tego pojęcia opartą na czterech wymiarach (lub aspektach):

\footnotetext{
14 R. Cichocki, Podmiotowość w społeczeństwie, Poznań 2003.

15 A. Siatkowski, Kompetencje obywatelskie a aktywność w sferze publicznej, Poznań 2014.
} 
a) poznawczym, b) ewaluacyjnym, c) normatywnym i d) sprawczym. W tym ujęciu struktury analizowanego pojęcia przyjęto, że kluczowe elementy wymiaru motywacyjnego w rzeczywistości mogą być traktowane jako składniki dwóch innych wymiarów: ewaluacyjnego i normatywnego. Jest to zgodne z wymiarami podmiotowości jednostki w społeczeństwie, której próba konceptualizacji została przedstawiona w wymienionej już pracy R. Cichockiego ${ }^{16}$.

\section{Wymiar poznawczy kompetencji obywatelskiej}

Ten wymiar kompetencji obywatelskiej jest odpowiedzialny za monitorowanie przez podmiot kluczowych elementów sfery publicznej i uczestniczących w tej sferze podmiotów, a polega na nakładaniu siatek pojęć i schematów poznawczych zawartych w dwóch rodzajach wiedzy: opisowej i pragmatycznej ${ }^{17}$. Pierwsza z nich umożliwia definiowanie stanów rzeczy, działan, zjawisk i procesów zachodzących w sferze publicznej, czyli podstawową strukturalizację rzeczywistości w tym obszarze. Natomiast druga pozwala jednostce scharakteryzować skutki wpływu własnego i wpływu innych podmiotów sfery publicznej na jej struktury oraz zachodzące w niej procesy.

Wymiar poznawczy kompetencji obywatelskiej obejmuje w naszym przekonaniu trzy elementy: a) zdolność podmiotu do rozwijania i budowania zasobów wiedzy niezbędnej do funkcjonowania w sferze publicznej, b) skumulowane zasoby tej wiedzy oraz c) zdolność podmiotu do efektywnego wykorzystywania tej wiedzy w aktywności obywatelskiej, tak aby zagwarantować skuteczność tych działań na poziomie przyjętych standardów. Dla zagwarantowania tej skuteczności poznawczej podmiotu jego kompetencja poznawcza powinna stwarzać możliwość: określonego poziomu opisu struktur przestrzeni publicznej, zjawisk i procesów zachodzących w sferze publicznej, określonego stopnia precyzyjności definiowania stanów rzeczy, sytuacji, zdarzeń w sferze publicznego, określonego rozumienia skutków oraz konsekwencji działań własnych i działań innych podmiotów uczestniczących w sferze publicznej, wreszcie określoną dokładność prognozowania kierunku przebiegu zjawisk w sferze publicznej, trendów zmian procesów w sferze publicznej, skutków działań podmiotów indywidualnych i zbiorowych w sferze publicznej.

\section{Wymiar ewaluacyjny kompetencji obywatelskiej}

Ten wymiar kompetencji obywatelskiej jest odpowiedzialny za dokonywanie ocen: poszczególnych elementów sfery publicznej, działań uczestniczących w niej podmiotów indywidualnych i zbiorowych oraz wszelkich procesów za-

16 R. Cichocki, Podmiotowość...

17 A. Siatkowski, Kompetencje obywatelskie... 
chodzących w jej obrębie, niezależnie od tego, czy są one efektem działań tych podmiotów, czy też zachodzą w sposób niekontrolowany ${ }^{18}$.

Wymiar ewaluacyjny kompetencji obywatelskiej obejmuje odpowiednio cztery elementy: a) posiadanie i umiejętność wykorzystania własnych źródeł ewaluacji - wartości, interesów, potrzeb, tożsamości, tradycji, identyfikacji; b) umiejętność samodzielnego wyprowadzania kryteriów ewaluacji z własnych źródeł ewaluacji i efektywnego posługiwania się tymi kryteriami do oceny rzeczywistości; c) umiejętność tworzenia własnych standardów ewaluacji odnoszących się do poszczególnych kryteriów ewaluacji i wykorzystywanie ich w procesach oceny różnych elementów sfery publicznej; d) umiejętność samodzielnego wyprowadzania własnych relacji preferencji (na podstawie dostępnych kryteriów i standardów ewaluacji), niezbędnych do oceny instytucji, zdarzeń i procesów w sferze publicznej. Aby zagwarantować skuteczność ewaluacyjną podmiotu, wymienione narzędzia ewaluacji powinny stwarzać podmiotowi możliwości: oceny ram prawnych (przyjętych rozwiązań prawnych i funkcjonujących instytucji prawa) z perspektywy własnych źródeł ewaluacji podmiotu (wartości, interesów itp.), oceny rozwiązań instytucjonalnych przyjętych w systemie politycznym oraz funkcjonowania instytucji ustawodawczych i wykonawczych państwa, oceny zarówno programów politycznych, jak i realnych kierunków działania partii politycznych i możliwość wyboru najwyżej akceptowanej z perspektywy własnych źródeł ewaluacji podmiotu, oceny obecności i funkcjonowania w sferze publicznej innych podmiotów starających się wywierać wpływ na kształt i funkcjonowanie sfery publicznej, samooceny swojej obecności w sferze publicznej i jej skutków dla funkcjonowania tej sfery.

\section{Wymiar normatywny kompetencji obywatelskiej}

Podstawowym zabiegiem kontroli normatywnej sfery publicznej realizowanej przez podmioty indywidualne i zbiorowe jest osądzanie, czyli odnoszenie przyjętych rozwiązań prawnych i instytucjonalnych w sferze publicznej, działań podmiotów w tej sferze, efektów tych działań oraz procesów prze nie wywoływanych ${ }^{19}$.

Wymiar normatywny kompetencji obywatelskiej obejmuje porównywanie ze sobą dwóch (lub większej liczby) stanów rzeczy, trendów, procesów, działań itd. z wykorzystaniem relacji osądzania, poprzez odniesienie ich do kryteriów i standardów normatywnych obecnych w sferze publicznej i istotnych dla podmiotu dokonującego osądu normatywnego. Kompetencja normatywna podmiotu oparta jest na posiadaniu kluczowego składnika, tzn. ukrytych założeń normatywnych ${ }^{20}$

18 Ibidem.

19 Ibidem.

20 J. Reykowski, Ukryte założenia normatywne jako osiowy składnik mentalności, [w:] Orientacje społeczne jako element mentalności, red. J. Reykowski, K. Skarżyńska, M. Ziółkowski, Poznań 1990. 
oraz zdolności do wyprowadzania z nich kryteriów normatywnych, standardów normatywnych i konkretnych relacji osądzania ${ }^{21}$. Mówimy o dwóch rodzajach osądzania. Pierwszym, który umożliwia porządkowanie działań własnych i działań innych podmiotów z punktu widzenie kryteriów normatywnych (np. moralnych). Drugim, polegającym na analogicznych odniesieniach do standardów normatywnych (np. ukształtowanych standardów uczciwości).

\section{Wymiar sprawczy kompetencji obywatelskiej}

Wymiar sprawczy kompetencji obywatelskiej polega na zdolności podmiotu do wpływania na różne elementy i aspekty sfery publicznej, czyli na redukowaniu dystansów rozdźwięków pomiędzy realnymi stanami rzeczy (trendami zachodzących procesów, rezultatami działań itp.) a stanami rzeczy preferowanymi w świetle akceptowanych przez podmiot kryteriów i standardów ewaluacyjnych i normatywnych ${ }^{22}$. Efektywne wykorzystanie kompetencji sprawczej to - ogólnie rzecz biorąc - umiejętność wykorzystania przez podmiot swoich zasobów do kształtowania sfery publicznej i procesów w niej zachodzących.

W świetle dotychczasowych ustaleń przyjmujemy, że kompetencja obywatelska wiąże się z posiadanymi przez podmioty możliwościami kontroli sfery publicznej (rozumianej w naszkicowany powyżej sposób) poprzez wykorzystanie adaptacyjnego lub podmiotowego modelu kontroli otoczenia. Kompetencja obywatelska podmiotu to - z jednej strony - zasoby podmiotów zarówno indywidualnych, jak i zbiorowych: a) poznawczych - wiedza opisowa i wiedza pragmatyczna, b) ewaluacyjnych - źródła kryteriów ewaluacji (wartości, interesy, tradycje, ideologie), kryteria ewaluacji, standardy ewaluacji i konkretne relacje preferencji, c) normatywnych - ukryte założenia normatywne, kryteria normatywne, standardy normatywne i relacje osądzania, d) sprawczych oraz - z drugiej strony - posiadane zdolności wykorzystania tych wszystkich narzędzi kontroli sfery publicznej jej rozumienia, oceniania, osądzani i kształtowania. Oznacza to, że wszelkie próby operacjonalizacji tego pojęcia powinny uwzględniać każdy z czterech omówionych aspektów kompetencji obywatelskiej.

Wymiar sprawczy kompetencji obywatelskiej polega na zdolności podmiotu do wpływania na różne elementy i aspekty sfery publicznej, czyli na redukowaniu dystansów rozdźwięków pomiędzy realnymi stanami rzeczy (trendami zachodzących procesów, rezultatami działań itp.) a stanami rzeczy preferowanymi w świetle akceptowanych przez podmiot kryteriów i standardów ewaluacyjnych i normatywnych ${ }^{23}$.

\footnotetext{
${ }^{21}$ R. Cichocki, Podmiotowość...

${ }^{22}$ Ibidem.

${ }^{23}$ Ibidem.
} 


\section{Przemiany kompetencji obywatelskiej w lokalnych sferach publicznych - poziomy aktywności obywatelskiej}

Jakim zmianom ulegała w interesującym okresie kompetencja obywatelska członków społeczności lokalnych w czterech wspomnianych wymiarach: sprawczym, poznawczym, normatywnym i aksjologicznym?

Można mówić o czterech poziomach indywidualnej aktywności obywatelskiej i czterech poziomach indywidualnej kompetencji obywatelskiej odpowiadającej tym poziomom aktywności. Są to kompetencje odpowiadające: a) prostemu, adaptacyjnemu uczestnictwu w sferze publicznej, b) rozszerzonemu, adaptacyjnemu uczestnictwu w sferze publicznej, c) podmiotowemu, niekonfliktowemu uczestnictwu w sferze publicznej, d) podmiotowemu, potencjalnie konfliktowemu uczestnictwu w sferze publicznej. Przyjmuję, iż uczestnictwo o charakterze adaptacyjnym polega na braniu udziału w różnych formach aktywności obywatelskiej, wpisanej w funkcjonowanie systemu politycznego, przy akceptacji tego systemu, bez próby przekształcania czy kwestionowania zastanego ładu, natomiast uczestnictwo o charakterze podmiotowym oznacza udział w tych formach aktywności obywatelskiej, które kwestionują albo istniejący porządek, albo przynajmniej niektóre jego aspekty, a celem aktywności jest zmiana pewnych elementów ładu (wersja umiarkowana) lub zmiana całości ładu (zmiana radykalna).

\section{Kompetencja obywatelska aktywności obywatelskiej na poziomie adaptacyjnego uczestnictwa}

Pierwszy poziom aktywności obywatelskiej, proste, adaptacyjne uczestnictwo, to udział w takich przedsięwzięciach, jak spotkania z grupami mieszkańców, władzami lokalnymi, indywidualne lub zbiorowe wizyty u przedstawicieli władz lokalnych, korespondencja z mediami i władzami lokalnych, wybory samorządowe lub referenda. Ten typ aktywności obywatelskiej ma charakter biernego uczestnictwa (potrzeba uczestnictwa i bycia poinformowanym, bez potrzeby wpływania na decyzje i bieg zdarzeń) w przedsięwzięciach organizowanych przez innych aktorów sfery publicznej - zarówno instytucjonalnych, zbiorowych, jak i indywidualnych.

Poziom kompetencji sprawczej (wiedzy pragmatycznej i umiejętności wpływania na rzeczywistość społeczną) w przypadku aktywności pierwszego poziomu, polegającego na adaptacyjnym uczestnictwie $\mathrm{w}$ przedsięwzięciach organizowanych przez innych aktorów sceny publicznej, nie odbiega zasadniczo od potocznej wiedzy posiadanej przez każdego obywatela w minimalnym przynajmniej stopniu przygotowanego do rozumienia otoczenia społecznego. Ogranicza się ona do prostej wiedzy pragmatycznej mówiącej, iż podstawowym źródłem decyzji kształtujących życie społeczności lokalnej są władze lokalne, a więc różne formy wpływu na ich wybór oraz formułowanie i upowszechnianie własnych opinii na temat oczekiwanych kie- 
runków ich działania, co zwiększa szanse uzyskania preferowanych stanów rzeczy. Taka wiedza pragmatyczna i związane z nią umiejętności działania są dostępne w postaci potocznej wiedzy społecznej dla przeciętnie wykształconego obywatela - i ten poziom kompetencji sprawczej upowszechnił się już w pierwszych latach po reformie samorządowej, tym bardziej że wiele doświadczeń poprzedniego systemu, nawet bez zasadniczych przekształceń, były źródłem wielu wzorców działania społecznego.

Poziom kompetencji poznawczej (zdolności do poznawczej kontroli otoczenia w sferze publicznej) odpowiadającej temu poziomowi zaangażowania jest oparty na wiedzy pozwalającej rejestrować i śledzić najważniejsze wydarzenia w otoczeniu społecznym, bez głębszego ich rozumienia, a tym bardziej bez zdolności do przewidywania ich przebiegu i skutków. Wiedza ta ma charakter opisowy, powierzchowny, fragmentaryczny i nie stanowi spójnego obrazu rzeczywistości w obrębie społeczności lokalnej. Ten poziom kompetencji poznawczej także zasadniczo mieści się w codziennym, skumulowanym doświadczeniu społeczności lokalnych.

Poziom kompetencji aksjologicznej (umiejętności oceny zachowań innych aktorów sceny publicznej, stanów rzeczy, zjawisk, procesów społecznych) odpowiadający aktywności na tym poziomie ogranicza się do umiejętności operowania pierwszym poziomem oceniającym, tzn. posiadaniem własnych relacji preferencji (co jest dobre dla mnie i osób ze mną związanych) w odniesieniu do niektórych procesów, stanów rzeczy, działań, funkcjonowania instytucji i osób publicznych, jednak bez zdolności do samodzielnego korzystania z takich narzędzi ewaluacji jak kryteria wartości i standardów wartości.

Poziom kompetencji normatywnej (zdolność osądzania działań własnych i działań innych podmiotów z perspektywy przyjętych założeń normatywnych) jest oparty na osądach dokonywanych w życiu codziennym i nie jest wykorzystywana żadna wersja osądzania odnosząca się specjalnie do sfery publicznej, stosująca świadomie kryteria i standardy normatywne.

\section{Kompetencja obywatelska aktywności obywatelskiej na poziomie rozszerzonego, adaptacyjnego uczestnictwa}

Drugi poziom aktywności obywatelskiej, rozszerzone, adaptacyjne uczestnictwo, to uczestnictwo w rolach organizatorskich, a więc takich, w których realizowany jest udział w: pracach zespołów roboczych rady miasta, pracach rad gmin i rad osiedli, pracach nad strategią rozwoju lokalnego, przedsięwzięciach związanych z kształtowaniem sąsiedztwa, na rzecz bezpieczeństwa zbiorowego. Polega na aktywnym udziale (potrzeba uczestnictwa, poinformowania i rozumienia, uczestniczenia w działaniach wpływających na decyzje i bieg zdarzeń), w przedsięwzięciach organizowanych przez innych aktorów sfery publicznej.

Przy drugim poziomie aktywności (rozszerzonej, adaptacyjnej) niezbędny jest bardziej rozwinięty i bogatszy zasób kompetencji sprawczej. Uczestnictwo w pracach takich jak wymienione wyżej wymaga bardziej zaawansowanej wiedzy pragmatycznej 
o możliwych sposobach wpływania na decyzje zapadające w strukturach instytucjonalnych, o ramach prawnych funkcjonowania struktur instytucjonalnych oraz potencjałach i barierach stwarzanych przez te ramy, o udziale w zachowaniach zbiorowych, w których podejmowane są decyzje, a także o oczekiwanych efektach działań własnych i ich bezpośrednich skutkach. Ten zakres kompetencji sprawczej zasadniczo wybiega poza doświadczenie potoczne i kształtuje się najczęściej w wyniku kumulowania doświadczeń nabywanych we wcześniejszych działaniach zbiorowych i indywidualnych o podobnym charakterze, a także w wyniku transferu doświadczeń innych podmiotów.

Przy tym poziomie aktywności niezbędna jest rozszerzona kompetencja poznawcza, znacząco wychodząca poza dostępną w codziennym doświadczeniu potocznym. Uczestnicy muszą mieć wiedzę o sferze publicznej w zakresie niezbędnym do śledzenia sytuacji zachodzących w społeczności lokalnej, działań i skutków działań władzy i innych podmiotów sfery publicznej, rozumienia zmian zachodzących w społeczeństwie, trendów tych zmian i ich bliskich konsekwencji. Wiedza niezbędna dla tego poziomu aktywności jest połączeniem wiedzy teoretycznej, dostępnej w systemie edukacyjnym społeczeństwa i obiegu publicznym, $\mathrm{z}$ wiedzą potoczną kumulowaną w wyniku wcześniejszych doświadczeń.

Kompetencja ewaluacyjna dla tego poziomu aktywności wymaga samodzielnego operowania nie tylko prostymi relacjami preferencji (co jest dobre, a co złe - dla zbiorowości), ale także rozumienia kryteriów, według jakich takich ocen się dokonuje, oraz standardów wartości, do których odnosi się stany rzeczy z otaczającej rzeczywistości. Niezbędna jest zdolność do oceny funkcjonowania instytucji sfery publicznej, podmiotów politycznych, osób publicznych i głoszonych przez nich poglądów.

Poziom kompetencji normatywnej jest oparty nie tylko na osądach dokonywanych w życiu codziennym, ale wykorzystywane są inne narzędzia kontroli normatywnej odnoszące się do sfery publicznej, np. świadome wykorzystywanie kryteriów i standardów normatywnych.

\section{Kompetencja obywatelska aktywności obywatelskiej na poziomie podmiotowego, niekonfliktowego uczestnictwa}

Trzeci poziom aktywności obywatelskiej, niekonfliktowe, podmiotowe uczestnictwo w sferze publicznej, to udział w takich przedsięwzięciach, jak projektowanie i organizowanie działań zbiorowych na rzecz: kształtowania sąsiedztwa społecznego i przestrzennego, ochrony środowiska i zachowania zasobów przyrodniczych, bezpieczeństwa zbiorowego, zdrowia społecznego, sportu i rekreacji, czasu wolnego, rozrywki i uczestnictwa w kulturze, własnego środowiska religijnego, własnego środowiska politycznego, wsparcia osób potrzebujących pomocy. Polega na samodzielnym (inicjatywa indywidualna lub udział w inicjatywie grupowej) kształtowaniu aktywności w ramach przyjętego porządku prawnego i instytucjonalnego, połączonego z umiarkowanymi próbami modyfikowania tych porządków, poprzez wpływanie na rozwiązania prawne (przynajmniej w odniesieniu do prawa lokalnego), funkcjonowanie instytucji lokalnych (przede wszystkim na kształt decyzji 
władz), zachowania członków społeczności lokalnej (przede wszystkim wpływanie na wzory i standardy zachowań innych członków społeczności lokalnej).

Dla uruchamiania podmiotowego typu aktywności podmiotowej zdroworozsądkowa wiedza pragmatyczna nie jest wystarczająca. Stopień skomplikowania społecznego i organizacyjnego oraz sieciowy charakter takich przedsięwzięć wymaga, aby uczestniczący w niej ludzie posiadali bardziej zaawansowane i wyspecjalizowane postacie wiedzy pragmatycznej i umiejętności z zakresu działania zbiorowego. Kumulują się one w wyniku wcześniejszych działań zbiorowych lub w procesach określanych przez A. Etzioniego jako aktywne samouczenie się $e^{24}$. Ten rodzaj kompetencji sprawczej jest $\mathrm{w}$ społecznościach lokalnych naszego kraju ciągle w fazie początkowego kształtowania się $\mathrm{i}-\mathrm{w}$ wymiarze indywidualnym - pozostaje $\mathrm{w}$ dyspozycji jedynie niewielkiego odsetka uczestników lokalnych sfer publicznych. Efektywne uczestnictwo w takim typie aktywności obywatelskiej ogranicza się do bardzo wąskiego grona członków społeczności lokalnych, osób, które są wyposażone w odpowiednie predyspozycje osobowościowe (naturalnie ukształtowani lub wyszkoleni liderzy), a także zakres pragmatycznej wiedzy o ludziach i ich zachowaniach, grupach społecznych, zakres zachodzących w nich procesach, strukturach instytucjonalnych i ich działaniach, ze szczególnymi elementami bycia liderem społecznym w inicjowaniu działań obywatelskich i bycia kierownikiem w trakcie realizacji tych działań. Aby spełniać te wymogi, niezbędne jest posiadanie pewnego kompleksu cech osobowych, związanych z funkcjonowaniem w zespołach społecznych. Proces kreowania tego typu aktywności był zdecydowanie dłuższy, ponieważ już samo pozytywne wyselekcjonowanie osób o cechach liderów wymagało czasu, a ponadto musieli oni jeszcze skumulować niezbędną wiedzę i doświadczenie, albo w wyniku własnej działalności, albo poprzez udział w specjalistycznych szkoleniach. Jednak segment ,citizen engagement” programu badawczego o charakterze monitorującym Wskaźniki jakości życia mieszkańców Poznania, realizowanego od 2002 r., wskazuje na znaczące zakorzenienie się takiej wiedzy pragmatycznej w doświadczeniach znaczących grup społecznych ${ }^{25}$.

Niezbędna jest rozwinięta kompetencja ewaluacyjna i normatywna w zakresie opisanym w poprzednim podrozdziale, czyli efektywne wykorzystanie narzędzi oceny i osądu w odniesieniu do wszystkich kluczowych elementów sfery publicznej.

\section{Kompetencja obywatelska aktywności obywatelskiej na poziomie podmiotowego, potencjalnie konfliktowego uczestnictwa}

Czwarty najbardziej zaawansowany typ tej aktywności, podmiotowe i potencjalnie konfliktowe uczestnictwo w sferze publicznej, to wreszcie udział w takich przedsięwzięciach, jak: pisanie listów protestacyjnych, spotkania przygotowujące protest przeciwko działaniom władzy, spotkania $\mathrm{z}$ władzami będące formą sprze-

\footnotetext{
24 A. Etzioni, The Active Society. Theory of Social and Political Processes, London 1969.

${ }^{25}$ R. Cichocki, Wskaźniki jakości życia mieszkańców Poznania, Poznań 2005.
} 
ciwu wobec ich działań, protesty i pikiety pod budynkami publicznymi, legalne i nielegalne manifestacje, protesty i blokady dróg, wywieranie ukierunkowanych nacisków na władzę samorządową. Polega na samodzielnym (także indywidualnym albo zbiorowym) kształtowaniu aktywności w sferze publicznej, ale ze świadomością, że preferowane rozwiązania mogą być zrealizowane jedynie w warunkach konfliktu $\mathrm{z}$ istniejącym: porządkiem prawnym (w odniesieniu do prawa lokalnego i/lub państwowego, a nawet międzynarodowego), porządkiem instytucjonalnym (lokalnym i/lub państwowym), systemami wartości i/lub interesów innych podmiotów społecznych (lobby, grupy interesu wewnątrz systemu instytucji, lokalne ośrodki wpływu, polityczne grupy wpływu, kliki), istniejącymi i utrwalonymi wzorami zachowań społecznych w obrębie społeczności lokalnej (brak dbałości o stan środowiska, powszechne występowanie zachowań antyspołecznych).

Uczestnictwo w aktywności czwartego typu, czyli realizowanie podmiotowe swoich celów w warunkach konfliktu, wymaga zasadniczo odmiennej kompetencji sprawczej. W zależności od tego, jaki aktor sceny publicznej jest drugą stroną konfliktu: instytucja publiczna, lokalny układ władzy, partie polityczne, lokalne środowiska wpływu, wpływanie na bieżące sytuacje i zdarzenia, procesy i trendy w społeczności, decyzje władzy wymaga wyspecjalizowanej wiedzy o instytucjach publicznych i ich funkcjonowaniu, o ramach prawnych oraz tkwiących w nich możliwościach i barierach, interesach lokalnych elit wpływu, wartościach istotnych dla społeczności lokalnej itd. Jest to niezbędne, aby zdefiniować obszary, które mają być poddane zmianie i znaleźć efektywne linie działania, umożliwiające dokonanie zmian. Ten typ wiedzy pragmatycznej i umiejętności działania koncentruje się w bardzo ograniczonych kręgach posiadających doświadczenia w działaniach społecznych zbudowanych na konflikcie.

Niezbędny poziom kompetencji poznawczej, odpowiadający temu typowi aktywności obywatelskiej, wymaga systematycznej wiedzy o obowiązujących rozwiązaniach prawnych i skutkach działań potencjalnie niezgodnych z prawem, skumulowanej wiedzy o mechanizmach działania instytucji publicznych i ich strategiach reagowania na sytuacje konfliktu społecznego, umiejętności rozumienia tych zjawisk i procesów zachodzących w sferze publicznej, które są istotne dla podejmowania działań społecznych, wiedzy o zachowaniu głównych aktorów sceny politycznej zarówno zbiorowych, jak i indywidualnych. Znaczące składniki kompetencji poznawczych na tym poziomie aktywności wymagają osób profesjonalnie przygotowanych, stąd występujący w rolach osób publicznych zawodowi: prawnicy, ekonomiści, socjologowie, politolodzy. Natomiast wiedza ta powstaje z połączenia wieloaspektowej wiedzy profesjonalnej z wiedzą kumulowaną w wyniku doświadczeń związanych z aktywnością w sferze publicznej.

Poziom kompetencji ewaluacyjnej niezbędny na tym poziomie aktywności wymaga świadomego operowania źródłami ewaluacji (wartościami, interesami, potrzebami) wykorzystywanymi do organizowania aktywności podmiotów, efektywnego wiązania ze źródłami ewaluacji kryteriów, standardów i reguł preferowania. Niezbędna jest w pełni rozwinięta kompetencja normatywna. 


\section{Zakończenie}

Trwałość zarysowanych wyżej przemian lokalnych sfer publicznych i towarzyszących im przemian kompetencji obywatelskiej uczestników sfery publicznej są poddawane systematycznym testom w postaci żywiołowych tendencji władzy centralnej do ponownej centralizacji systemu politycznego i - będącej konsekwencją tego dążenia - tendencji do ograniczania autonomii prawa i instytucji prawa, mediów i instytucji kultury, samorządów lokalnych i regionalnych. Instytucje samorządu lokalnego, lokalne układy społeczne i skumulowana kompetencja obywatelska może być jedną z kluczowych barier dla tych tendencji, na co wskazują doświadczenia społeczeństw i systemów politycznych państw Europy Zachodniej ${ }^{26}$.

\section{Bibliografia}

Cichocki R., Podmiotowość w spoleczeństwie, Poznań 2003.

Cichocki R., Wskaźniki jakości życia mieszkańców Poznania, Poznań 2005.

Cichocki R., Kilarska A., Życie w Lesznie 2014, Poznań 2015.

Etzioni A., The Active Society. Theory of Social and Political Processes, London 1969.

Frączak P., Rogaczewska M., Wygnański K., Stan spoleczeństwa obywatelskiego. Próba diagnozy, Warszawa 2005.

Giza A., Przybylska A., Partycypacja obywatelska: od teorii do praktyki społecznej, Warszawa 2014.

Habermas J., Strukturalne przeobrażenia sfery publicznej, Warszawa 2008.

Kalisiak-Mędelska M., Partycypacja społeczna na poziomie lokalnym jako wymiar decentralizacji administracji publicznej w Polsce, Łódź 2015.

Kuklinski J.H., Quirk J.P., Conceptual fundations of citizen competence, „Political Behaviour" 2001, no. 2(23), s. 285-311.

Pietrzyk-Reeves D., Idea spoleczeństwa obywatelskiego: współczesna debata i jej źródła, Wrocław 2004.

Reykowski J., Ukryte założenia normatywne jako osiowy sktadnik mentalności, [w:] Orientacje spoleczne jako element mentalności, red. J. Reykowski, K. Skarżyńska, M. Ziółkowski, Poznań 1990.

Rozdroża praktyki i idei społeczeństwa obywatelskiego, red. W. Miształ, A. Kościański, Warszawa 2011.

Siatkowski A., Kompetencje obywatelskie a aktywność w sferze publicznej, Poznań 2014.

Somers M., Citizenship and the place of the public sphere: Law, community, and the political culture in the transition tu democracy, „American Sociological Review” 1997, no. 58(5).

Wnuk-Lipiński E., Socjologia życia publicznego, Warszawa 2008.

${ }^{26}$ E.C. Banfield, Civility and Citizenship, New York 1991. 
Ryszard Cichocki

\section{Локальные публичные сферы и изменения в гражданской компетентности}

Отправной точкой настоящей статьи является концепция гражданской компетентности, разработанная Робертом Далем. На современном этапе принимается концептуализация данного понятия, основанная на четырех аспектах: а) познавательный аспект, б) оценочный аспект, в) нормативный аспект, г) исполнительный аспект. Настоящая статья является проектом имплементации указанной концепции, являясь в то же самое время предложением для локальных и региональных сообществ, которое позволит повысить гражданскую компетентность населения.

Ключевые слова: демократия, локальное сообщество, местное самоуправление, гражданская активность, публичная сфера, самоуправление.

\section{Ryszard Cichocki}

\section{Local public spheres and changes in civic competence}

The starting point for the present research paper is the concept of civic competence, which was originally formulated by R. Dahl. In the adopted model civic competence is viewed as a four-dimensional construct consisting of: cognitive competence, evaluative competence, normative competence and causative competence. The article comprises a project of implementation of this concept for the purpose of conducting research on local and regional communities as well as well as showing the possible ways of operationalization of the concept of civic competence.

Keywords: democracy, local society, local government, civic activities, public sphere, self-governments. 